\title{
Selection of Somaclonal Variants of Oats Resistant to Helminthosporium victoriae Which Produces a Host Specific Toxin, Victorin
}

\author{
Shigeyuki Mayama,* A.P. A. Bordin, Yukio Sasabe, Yasuharu Oishi \\ and Toshikazu TANI \\ Faculty of Agriculture, Kagawa University, Kagawa 761-07, Japan
}

(Received April 24, 1989)

(Accepted January 26, 1990)

\begin{abstract}
Somaclonal variation generated in tissue culture of oats was screened for insensitivity to victorin which is a host specific toxin produced by Helminthosporium victoriae. Mature embryos of oats (Iowa X 469) with the sensitive allele $V b(P c-2)$ were cultured in MS media with 2,4-D. Callus formation was best in $3.5 \mathrm{mg} / \mathrm{l}$ of $2,4-\mathrm{D}$. Continuous subcultures for every 2 weeks resulted in the induction of shoot, followed by the formation of root when cultured in hormone-free media. About 600 regenerated oat plants obtained from about 4000 calli were screened for resistance to victorin $\mathrm{D}$ which was found as a major toxin secreted during germination. Two regenerants showed toxin-tolerance. The progeny of one of the regenerants were all tolerant to the toxin, whereas that of the other segregated, suggesting that the former genotype is recessively homozygous and the latter is heterozygous. The toxin-insensitive regenerants were also highly resistant to the fungal infection.
\end{abstract}

Plant cell culture has been proposed as a means to produce agronomic plants in unconventional ways and thereby produce better plants, since a somaclonal variation frequently occurs through a tissue culture cycle. ${ }^{1-3}$ There have been many reports about resistance or tolerance to abiotic stresses such as salt, ${ }^{4)}$ aluminium, ${ }^{5)}$ herbicide ${ }^{6)}$ and selection of regenerated plants resistant to pathogens and/or the toxins. $^{7-9 ; 11)}$ Victorin is a host-selective peptide toxin produced by Helminthosporium victoriae which specifically infects oats carrying $P c$-2 gene. ${ }^{12)}$ The $P c$-2 gene has been known to be responsible for victorin-sensitivity and resistance to certain races of rust fungi, Puccinia coronata f. sp. avenae. ${ }^{12)}$ It has been suggested that victorin could function as a specific elicitor of avenalumin, phytoalexin of oats. ${ }^{13)}$ The selection of victorin-insensitive oat from the $P c-2$ line would be valuable not only from breeding point of view, but also for supplying the mutant line as an experimental material to elucidate the mechanisms of sensitivity to victorin and elicitation of avenalumin production. The present experiment was thus carried out to select a somaclonal variant resistant to victorin among the regenerants obtained through tissue culture of oat Iowa X 469 with victorin-sensitive $P_{c}$-2 gene.

\section{Materials and Methods}

Plant materials and tissue culture conditions. Seeds of oat, cultivar Iowa X 469 carrying the oat $P c$-2 gene were supplied by Dr. N. T. Keen, University of California, Riverside, U.S. A. Mature seeds were sterilized in $70 \%$ ethanol and $1 \%$ sodium hypochlorite for one and $20 \mathrm{~min}$, respectively. Embryos were aseptically excised and placed onto MS medium supplemented with $0.5 \mathrm{mg} / \mathrm{l}-10 \mathrm{mg} / \mathrm{l} 2,4$-D at $25^{\circ} \mathrm{C}$ under continuous illumination $(6,000 \sim 8,000 \mathrm{lux})$. Calli were subcultured every 2 weeks in the same medium and maintained at $25^{\circ} \mathrm{C}$ under continuous illumination. When shoots were regenerated,

* Present Address : Faculty of Agriculture, Kobe University; Rokkodaicho 1 chome, Nada-ku, Kobe 657, Japan. 
the calli with shoots were transferred to the hormone-free media for induction of adventitious root. Further proliferation of the root was obtained by placing the plantlets on a filter paper wetted with water in glass bottles. The regenerants were finally planted in a pot with vermiculite and soli $(1: 1)$ mixture and grown in a growth chamber with $8 \mathrm{hr}$ photoperiod for about 2 weeks. The plants were then transplanted into pots with soil and maintained in a phytotron at $20^{\circ} \mathrm{C}$ and $75 \%$ humidity until maturity. Seeds of regenerants were harvested from each individual panicle and named as $R_{1}$ seeds. The following $R_{2}$ and $R_{3}$ generations of mutant regenerants were also obtained.

Bioassay with victorin and fungal infection. The host specific toxin, victorin $\mathrm{D}$ was purified from the culture fluid of Helminthosporium victoriae, isolate $\mathrm{Hv}-1$, as described previously ${ }^{13)}$ and used for victorin-reaction bioassay. Several leaf segments of $3 \mathrm{~mm}$ long were taken from the terminal portion of primary leaves of all regenerants and placed in various dilutions of victorin kept in multiplate wells for $24 \mathrm{hr}$ at $25^{\circ} \mathrm{C}$ under continuous illumination. The sensitivity or insensitivity of the regenerants were determined by the development of necrosis. The technique could distinguish genotypes of $P c$-2, dominantly homozygous, heterozygous and recessively homozygous by the differential responses to various concentrations of the toxin. The seeds of progenies of the regenerants were also assayed for victorin by using the primary leaves of Iowa X 469, dominantly homozygous $P c-2$ and Iowa X 424, recessively homozygous, as control. The regenerants resistant to victorin were inoculated with conidia of $H$. victoriae to confirm resistance of the plants against the fungal infection.

\section{Results}

\section{Induction of callus and regeneration}

Five mature embryos of aat, Iowa X 469, with $P c$-2 gene were plated on MS media in different concentrations of 2,4-D. Callus formation. was initiated from the mesocotyl portion of the embryos in all concentrations of 2,4-D about 3 days after plating. Callus induction and the growth were the best on the medium containing $3.5 \mathrm{mg} / l 2,4$-D. The induced callus was then removed from the embryos three weeks after plating and subcultured for every two weeks thereafter. Callus growth on medium containing $0.5-1.0 \mathrm{mg} / \mathrm{l} 2$, 4 -D was generally slower than that on $3.0-3.5 \mathrm{mg} / \mathrm{l} 2$, 4 -D. The early signs of organization in the from of localized chlorophyll development, green spots, were formed in the callus induced from all five seeds which were maintained at $3.5 \mathrm{mg} / / 2,4$-D about 40 to 50 days after the first subculture. The calli were then transferred onto the medium without 2,4-D which is usually used for induction of plant differentiation. However, the differentiation of shoots was rarely induced from the green spots. Leaves and shoots were differentiated from green regions of the callus about 10 days after the development of green spots when the callus was maintaned continuously in the medium with $3.5 \mathrm{mg} / \mathrm{l} 2,4$-D (Fig. $1 \mathrm{~A}$ ). When the typical regenerated shoots developed 1 or 2 roots, the plants.were further cultured on the hormone-free media to induce more root formation. The plants were then transferred onto a paper wick in water to proliferate more roots for about two weeks. After confirming the good growth of roots, the regenerants were transplanted to soil mixed with vermiculite. The plants were then transplanted into soil in pots and grown to maturity in the greenhouse. The 584 oat plants were regenerated from the cell lines obtained from embryos plated in the media with $3.5 \mathrm{mg} / \mathrm{l} 2,4-\mathrm{D}$. The frequency of plant regeneration was different not only among the cell lines but also among the seeds (Table 1).

\section{Victorin selection}

The sensitivity of regenerated plants to victorin was examined with the tip portion of primary leaves by the microplate bioassay which is useful to identify the genotypes of $P c$ - 2 gene, dominantly homozygous, heterozygous and recessively homozygous by the differential responses to various concentrations of victorin (Fig. 1 B). Two victorin-tolerant plants were screened through the biassay and grown to maturity. One plant produced 2 panicles with 100 and 11 seeds, respectively, and the other gave 4 panicles with 110, 11.0, 60 and 58 seeds respectively. The progeny plants were also tested for victorin sensitivity. The plants obtained from two panicles of one toxin-insensitive regenerant No. 7 were all 

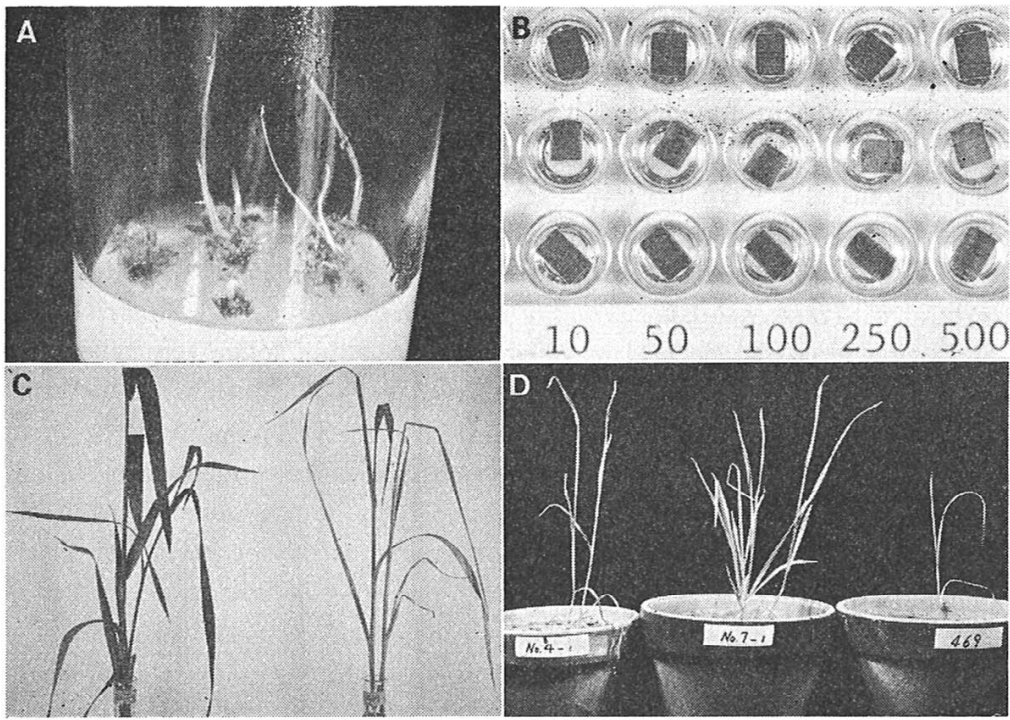

Fig. 1. Regeneration of plants from callus of oat cultivar, Iowa X 469, which is susceptible to $H$. victoriae and a host-specific toxin, victorin and screeningof regenerants resistant to the toxin and the fungal infection. A : Shoots regenerated on MS medium with $3.5 \mathrm{mg} / \mathrm{l}$ 2, 4-D. B : A microplate bioassay for victorin sensitivity. The number shows concentration of victorin in $n g / l$. Leaf segments of the top, second and third rows are the toxinresistant cultivar, Kanota, the $P c-2$ line sensitive to victorin and the $F_{1}$ hybrid showing an intermediate response to the toxin, respectively. C: Mature R 1 plant of victorin-resistant regenerant No. 7 was also resistant to the toxin (left) as contrasted to the parental plant, Iowa X 469. D: Bioassay of $\mathrm{R} 1$ plants to $H$. victoriae infection. A plant $\mathrm{R} 1$ from regenerant No. 7 (center) was resistant to the fungal infection, whereas a $\mathrm{R} 1$ plant obtained from regenerant No. 4 (left) which was sensitive to the toxin and a parent plant, Iowa X 469 (right), were completely damaged by the heavy inoculation.

Table 1. Performance of oat, Iowa $X 469$, with $P c-2$ gene in tissue culture

\begin{tabular}{cccccc}
\hline \multirow{2}{*}{ Seed No. } & Cell line & Callus growth & No. of Plants regenerated & \multicolumn{2}{c}{ Victorin- } \\
sensitive & resistant \\
\hline \multirow{2}{*}{1} & OC-28 & ++ & 320 & 319 & 1 \\
& OC-37 & ++ & 3 & 3 & \\
\multirow{2}{*}{2} & OC-38 & ++ & 93 & 93 & \\
& OC-31 & ++ & 12 & 12 & \multirow{2}{*}{3} \\
\multirow{2}{*}{3} & OC-40 & ++ & 130 & 129 & 1 \\
& OC-27 & ++ & 23 & 23 & \\
5 & OC-36 & ++ & 1 & 1 & \\
5 & OC-29 & ++ & 1 & 1 & \\
\hline
\end{tabular}

${ }^{++}$indicates good growth.

resistant to victorin and those of the other regenerant No. 4 segregated into the ratio of about 10 sensitive to one insensitive which differs from the expected ratio (Table 2). The mature leaves of the progeny of the regenerant No. 7 were insensitive to victorin (Fig. 1 C) and completely resistant to the 
Table 2. Segregation for victorin-sensitivity in the progeny of regenerated oat plants selected as tolerant to victorin.

\begin{tabular}{cccc}
\hline Progeny No.* & No. of Seed & Sensitive & Tolerant \\
\hline $7-(1)$ & 100 & 0 & 100 \\
$7-(2)$ & 11 & 0 & 11 \\
$4-(1)$ & 110 & 101 & 9 \\
$4-(2)$ & 110 & 106 & 4 \\
$4-(3)$ & 60 & 57 & 3 \\
$4-(4)$ & 58 & 56 & 3 \\
\hline
\end{tabular}

* No. of selected regenerants and their panicles in parenthesis.

infection of $H$. victoriae whereas the parent and progeny plants sensitive to victorin were highly susceptible (Fig. 1 D).

\section{Discussion}

The oat $P c$ - 2 gene is of considerable interest because it appears to confer both resistance to certain races of the crown rust pathogen and sensitivity to a host-specific toxin, victorin secreted from Flelminthosporium victoriae. ${ }^{12)}$ Victorin has a role as a specific elicitor of avenalumin, phytoalexin of oats, whose accumulation appears to be important for the expression of resistance in the incompatible interactions between oat cultivars and fungal races.. ${ }^{13-15}$ )

In the present study, a tissue culture cycle of the $P c$-2 gene line, Iowa X 469 was established with the mature embryos. Previous works on tissue culture of oat were usually carried out with immature embryos as a source of tissue because of the higher regeneration ability, but the callus from mature embryos of Iowa X 469 obtained in this study also showed the long-duration of regeneration ability. Some of the cell lines are still regenerating plants after 30 subcultures in two years. The frequency of plant regeneration appears to depend on cell line of the calli and seeds.

Somaclonal variation in plant tissue culture has been considered as one of the unconvention'al breeding methods. ${ }^{2)}$ There are many reports on the selection of disease resistant plants from somaclonal variants induced in tissue culture cycle of plants. ${ }^{1,2,10,11)}$ As shown in this study, a somaclonal variant which is victorin-insensitive and resistant to the Victoria-blight fungus, H. victoriae was selected from the regenerated plants. One of the $R_{0}$ regenerants (No. 7) insensitive to the toxin was homozygously recessive, as suggested by the segregation data in $R_{1}$ plants. The traits of insensitivity to victorin and of resistance to the Helminthosporium pathogen were inherited in $\mathrm{R}_{2}$ and $\mathrm{R}_{3}$ plants. Leaves of the variant plant were also hairy and slightly narrower in width than those of the parent plant. The possible origins of somaclonal variation have been summarized as follows : karyotypic changes, cryptic chromosome rearrangements, transposable elements, somatic gene rearrangements, gene amplification and depletion, somatic crossing over and sister chromatid exchanges. ${ }^{3)}$ The toxin-insensitive mutant obtained in the present experiment could be induced by deletion of the locus with $P c-2$. However, the detailed mechanism of the variation is not known. Genetical characterization of the mutant No. 7 plant is now under investigation.

It has been suggested that toxins can be used in the selection media to improve the efficiency of selection of disease-resistant variants at cellular level. ${ }^{1)}$ Victorin-insensitive plants of oats were previously obtained through callus cultures induced from immature embryo of a heterozygous plant with $P c-2$ gene by selecting the callus resistant to the partially-purified victorin contained in media. ${ }^{10)}$ In the present experiment, however, we showed that selection of somaclonal variants resistant to the Helminthosporium blight is possible at the level of the regenerated plant without using the toxin during the callus culture. It has been told that regeneration of plants is usually difficult after long periods of in vitro selection against toxins and the phenotypes selected in culture systems containing 
toxins are sometimes not expressed in regenerated plants. Tobacco plants regenerated from the callus resistant to tenuazoic acid, a toxin produced by Alternaria alternata were susceptible to the toxin. ${ }^{16)}$ Thus, one can avoid the problem of differential gene expression at the cultured cell and whole-plant level, if a toxin-insensitive trait is being screened in the regenerated plant as shown in this study.

The victorin-insensitive mutant plant No. 7 obtained in this study could be useful as a control plant to the toxin-sensitive parent, Iowa X 469 for the study of mechanism of specific sensitivity to victorin. Also, a microplate bioassay for victorin sensitivity was useful for selecting the variants since only a tip portion of primary leaves of the regenerants was used for the in vitro bioassay, saving the remained seedlings for harvesting the seeds of the progeny. The technique can also distinguish the genotypes of $P c$-2 gene by the differential responses to various dilutions of victorin.

\title{
References
}

1) Daub, M. E., 1986. Ann. Rev. Phytopathol., 24 : 159-186.

2) Wenzel, G., 1985. Ann. Rev. Phytopathol., 23 : 149-172.

3) Larkin, P. J., Scowcroft, W. R., 1981. Theor. Appl. Genet., 60 : 197-214.

4) McHughen, A., 1987. Theor. Appl. Genet., 74: 727-732.

5) Conner, A. J., C. P. Meredith, 1985. Theor. Appl. Genet., 71: 159-165.

6) Thanutong, P., I. Furusawa, M. Yamamoto, 1983. Theor. Appl. Genet., 66 : 209-215.

7) Chaula, H.S., G. Wenzel, 1987. Theor. Appl. Genet., 74:841-845.

8) Gengenbach, B. G., C. E. Green, C. M. Donovan, 1977. Proc. Natl. Acad. Sci. USA, 74: 5113-5117.

9) Ling, D. H., P. Vidhyaseharan, E. S. Borromeo, F. Z. Zapata, T. W. Mew, 1985. Theor. Appl. Genet., $71: 133-135$.

10) Rines, H. W., H. H. Luke, 1985. Theor. Appl. Genet., 71 : 16-21.

11) Toyoda, H., Y. Matsuda, K. Shimizu, H. Ogata, H. Hashimoto, S. Ouchi, 1988. Plant Tissue Cult. Lett., $5:$ 66-71.

12) Scheffer, R. P., R. S. Livingston, 1984. Science, 233 : 17-21.

13) Mayama, S., T. Tani, T. Ueno, S. L. Midland, J. J. Sims, N. T. Keen, 1986. Physiol. Mol. Plant Pathol., 29: 1-18.

14) Mayama, S., T. Tani, Y. Matsuura, T. Ueno, H. Fukami, 1981. Physiol. Plant Pathol., 19: 217-226.

15) Mayama, S., Y. Matsuura, Y. Iida, T. Tani, 1982. Physiol. Plant Pathol., 30 : 189-199.

16) Kumashiro, T., 1983. Jpn. J. Breeding, 33: 194-195.

\section{《和文要約》}

エンバク再生植物体からの病原性毒素ビクトリン耐性ソマクローナル変異植物の選抜

真山滋志*, A. P. A. Bordin, 笹辺幸男, 大石康晴, 谷 利一

\author{
香川大学農学部
}

* 現在 : 神戸大学農学部

\begin{abstract}
エンバクの組織培養により再生した植物体から，エンバクビクトリア葉枯病菌 (Helminthosporium victoriae）の産生する宿主特異的毒素ビクトリンに対する耐性のソマクローナル変異体の選抜を行っ た. Pc-2 遺伝子保有, Iowa X 469 品種の完熟胚を $3.5 \mathrm{mg} / l$ 2, 4-D 含有 MS 培地で培養しカルスを 誘導させ，それを継代培養すると植物体が再生した．約 600 個の再生個体の初生葉に対するビクトリン 感受性を調べたところ, ビクトリン耐性の強い 2 個体が選抜され, その一つは, 自殖後代の分離により 完全な劣性ホモ型の抵抗性を示した. ビクトリン而性変異体の自殖後代植物に対する同葉枯病菌の胞子 を直接接種すると，同病害に対する明確な抵抗性発現が確認された.
\end{abstract}

